\title{
Territory acquisition mediates the influence of predators and climate on juvenile red squirrel survival
}

\author{
Jack G. Hendrix ${ }^{1,2}$ (D) | David N. Fisher,3 (D) | April Robin Martinig ${ }^{2}$ (D) | Stan Boutin ${ }^{4}$ (D) \\ Ben Dantzer ${ }^{5,6}$ (I) | Jeffrey E. Lane ${ }^{7}$ | Andrew G. McAdam ${ }^{2}$ (iD
}

${ }^{1}$ Cognitive and Behavioural Ecology Interdisciplinary Program, Memorial University of Newfoundland, St. John's, NL, Canada; ${ }^{2}$ Department of Integrative Biology, University of Guelph, Guelph, ON, Canada; ${ }^{3}$ Department of Psychology, Neuroscience \& Behaviour, McMaster University, Hamilton, ON, Canada; ${ }^{4}$ Department of Biological Sciences, University of Alberta, Edmonton, AB, Canada; ${ }^{5}$ Department of Psychology, University of Michigan, Ann Arbor, MI, USA; ${ }^{6}$ Department of Ecology \& Evolutionary Biology, University of Michigan, Ann Arbor, MI, USA and ${ }^{7}$ Department of Biology, University of Saskatchewan, Saskatoon, SK, Canada

Correspondence Jack G. Hendrix

Email: jackhendrixeco@gmail.com

\section{Funding information}

Natural Sciences and Engineering Research Council of Canada; Ministry of Research and Innovation; National Science Foundation; Northern Scientific Training Program

Handling Editor: Fanie Pelletier

\section{Abstract}

1. Juvenile survival to first breeding is a key life-history stage for all taxa. Survival through this period can be particularly challenging when it coincides with harsh environmental conditions such as a winter climate or food scarcity, leading to highly variable cohort survival. However, the small size and dispersive nature of juveniles generally make studying their survival more difficult.

2. In territorial species, a key life-history event is the acquisition of a territory. A territory is expected to enhance survival, but how it does so is not often identified. We tested how the timing of territory acquisition influenced the winter survival of juvenile North American red squirrels Tamiasciurus hudsonicus, hereafter red squirrels, and how the timing of this event mediated the sources of mortality. We hypothesized that securing a territory prior to when food resources become available would reduce juvenile susceptibility to predation and climatic factors overwinter.

3. Using 27 years of data on the survival of individually marked juvenile red squirrels, we tested how the timing of territory acquisition influenced survival, whether the population density of red squirrel predators and mean temperature overwinter were related to individual survival probability, and if territory ownership mediated these effects.

4. Juvenile red squirrel survival was lower in the years of high predator abundance and in colder winters. Autumn territory owners were less susceptible to lynx Lynx canadensis and possibly mustelid Mustela and Martes spp., predation. Autumn territory owners had lower survival in colder winters, but surprisingly non-owners had higher survival in cold winters.

5. Our results show how the timing of a life-history event like territory acquisition can directly affect survival and also mediate the effects of biotic and abiotic factors later in life. This engenders a better understanding of the fitness consequences of the timing of key life-history events. 


\section{KEYWORDS}

juvenile survival, life-history timing, lynx, mustelid, predation, red squirrel, Tamiasciurus,

territory

\section{1 | INTRODUCTION}

The juvenile age class, when individuals are no longer completely dependent on the parent but not yet sexually mature, is a crucial life-history stage for all taxa (Ferguson \& Fox, 1984; Gaillard, FestaBianchet, \& Yoccoz, 1998; Searcy \& Sponaugle, 2001). A large component of reproductive success is surviving to sexual maturity, hence juvenile survival can be a key determinant of lifetime fitness, and so variation in survival can dictate population dynamics (McAdam, Boutin, Sykes, \& Humphries, 2007; Oli \& Dobson, 2003). For example, rates of juvenile survival in mammals can be highly variable year-to-year and may be the key determinant of population dynamics (Gaillard, Festa-Bianchet, Yoccoz, Loison, \& Toïgo, 2000; Millar \& McAdam, 2001; Morrison \& Hik, 2007). Understanding the causes of variation in juvenile survival and the selection such variability facilitates therefore shapes how we expect populations to change over time.

The time period between juvenile independence and first breeding poses novel challenges to survival, as individuals at this stage must survive in the absence of the parental care on which they were previously dependent (Galef, 1981). Climatic factors can have strong effects on survival of juveniles (Fuller, Stebbins, \& Dyke, 1969; Schorr, Lukacs, \& Florant, 2009) through a combination of limited food availability and increased thermoregulatory costs (Jackson, Trayhurn, \& Speakman, 2001; Rödel et al., 2004), particularly overwinter. Due to their small size and lack of experience, as well as their dispersive nature, juveniles can also be particularly vulnerable to predation (Garrett \& Franklin, 1988; Rödel et al., 2015). Various behavioural and physiological responses such as adjusting metabolic rate (Wunder, Dobkin, \& Gettinger, 1977), activity (Merritt, 1986) or food caching (Morrison, Pelchat, Donahue, \& Hik, 2009) can mitigate this risk. Understanding how these mediating traits alter juvenile survival is necessary to understand how selection has resulted in the phenotypes we observe in the wild.

The acquisition of a territory is a key life-history event that can mediate the sources of mortality in some species, by providing access to space, refuges and food stores. Timing of life-history stages, such as birth or hatching (Rodríguez, van Noordwijk, Álvarez, \& Barba, 2016), or developmental rate (van der Jeugd \& Larsson, 1998) can have strong effects on survival at later life stages (O'Connor, Norris, Crossin, \& Cooke, 2014). Territory acquisition is one such event: predation risk is elevated while searching for territories (Larsen \& Boutin, 1994), and territory ownership also leads to increased food availability, particularly in food caching species. Earlier acquisition of a territory should, therefore, improve the probability of survival by reducing these risks earlier in life. It is well known that acquiring a territory provides benefits (reviewed in
Carpenter, 1987; e.g. Whitham, 1986). However, despite the potential importance of understanding how the timing of territory acquisition modifies juvenile survival and mediates sources of mortality, this has not yet occurred, in part due to the difficulty in collecting such data.

North American red squirrels Tamiasciurus hudsonicus are an ideal organism to study how the timing of territory acquisition influences survival and mediates sources of juvenile mortality. Red squirrels in Yukon, Canada defend exclusive individual territories with a central cache of white spruce Picea glauca cones, their primary food source (Smith, 1968). Holding a territory with a cache of food is considered necessary for red squirrels in these populations to survive overwinter (Larsen \& Boutin, 1994; Smith, 1968), as cached resources are essential for annual survival and reproduction (Fletcher et al., 2013; LaMontagne et al., 2013). White spruce cones ripen in early August, when caching begins and finishes once snow falls (Archibald et al., 2013; Fletcher et al., 2010), typically at the end of September. We hereafter refer to this period of time (mid-August to snowfall) as 'autumn'. Those juveniles with territories before this cone ripening occurs are able to take advantage of that year's cone crop and increase their hoard size, whereas those that settle on territories later in the season will acquire what is left from the previous owner but have no opportunity to secure further resources before winter (Fisher et al., 2019). Red squirrels may take advantage of periods of super abundant white spruce cones ('mast' years) to create new territories (Kelly, 1994; LaMontagne \& Boutin, 2007; Silvertown, 1980), in which case they only have access to what they can cache before snowfall. Vacant territories are typically rare, hence many juveniles cannot acquire one early or even at all (Fisher et al., 2017; Larsen \& Boutin, 1994).

Juvenile annual winter survival is low, with an average of $26.4 \%$ of all juveniles born surviving their first winter (McAdam et al., 2007), but this is highly variable annually (3\%-43\%; McAdam \& Boutin, 2003). Annual adult survival in this population is high ( $80 \%$ for 2 -year-old females; steadily decreasing with age; Descamps, Boutin, Berteaux, \& Gaillard, 2008), thus much of the variation in lifetime reproductive success is linked to juvenile overwinter mortality (McAdam et al., 2007). Acquiring a territory is therefore a key life-history event. However, the main causes of juvenile mortality, and how they are influenced by the timing of territory acquisition, remain unknown.

Observational studies, while relatively limited, have identified Iynx Lynx canadensis (Stuart-Smith \& Boutin, 1995), goshawks Accipiter gentilis (Larsen \& Boutin, 1994) and mustelids (Kerr \& Descamps, 2011; O'Donoghue, Boutin, Hofer, \& Boonstra, 2001) as predators of juvenile red squirrels (Goheen \& Swihart, 2005; Haines et al., 2018; Smith, 1968; Steele, 1998). Owning a territory, and thus having access to nests or tunnels, could act as spatial refugia and 
reduce vulnerability to predators (Cowlishaw, 1997; Everett \& Ruiz, 1993). Furthermore, red squirrels with smaller caches have lower winter survival (LaMontagne et al., 2013; Larivée, Boutin, Speakman, McAdam, \& Humphries, 2010), suggesting that resource limitation is a source of overwinter mortality. Owning a territory, and so regular use of nests, would provide thermal refugia during low temperatures (Greenwood \& Harvey, 1982; Studd, Boutin, McAdam, Krebs, \& Humphries, 2015). It therefore seems that a territory could both directly influence survival and change the suite of selection pressures that act on a juvenile red squirrel.

We aimed to better understand how the timing of territory acquisition affects juvenile overwinter survival and mediates sources of mortality. To do so we used 27 years of longitudinal data to assess how holding a territory before autumn influences survival and the susceptibility of a juvenile to predation or low temperatures overwinter.

Our first hypothesis was that earlier territory acquisition would result in higher overwinter survival compared to later territory acquisition (Berteaux \& Boutin, 2000). We further hypothesized that cold temperatures and predators pose a mortality risk, so that overwinter survival of juveniles would be lower in colder winters and when predators are abundant. Our key hypothesis is that timing of territory acquisition would moderate these effects, so that juveniles obtaining territories before autumn would be less susceptible to predators (e.g. Cowlishaw, 1997) and adverse weather (e.g. Greenwood \& Harvey, 1982) overwinter.

\section{MATERIALS AND METHODS}

\section{1 | Data collection}

Our study was part of the Kluane Red Squirrel Project, an ongoing long-term study of a wild population of North American red squirrels within the Champagne and Aishihik First Nations traditional territory along the Alaska Highway in southwestern Yukon, Canada $\left(61^{\circ} \mathrm{N}, 138^{\circ} \mathrm{W}\right)$. We collected data from two study areas ( $\sim 0$ hectares each) separated by the Alaska Highway from 1989 to 2015. We conducted population censuses biannually in May (spring) and August (autumn) to identify all individuals and assign territory ownership. The latter census roughly corresponds to the timing of caching; individuals can acquire territories after the August census, but these individuals would not be able to store cones from that year's production (Larivée et al., 2010). We assigned territory ownership based on territorial vocalizations ('rattling'; Lair, 1990) and behavioural observations. We also identified red squirrels that did not own territories in autumn through trapping and behavioural observations. Adult red squirrels rarely relocate, other than through bequeathals by mothers where all or a part of her territory is given to offspring (Berteaux \& Boutin, 2000; around 19\% of females do this each year; Lane et al., 2015; Larsen \& Boutin, 1994). Average juvenile dispersal distance is short $(M=92-102 \mathrm{~m}$; Berteaux \& Boutin, 2000; Cooper et al., 2017) relative to the size of our study areas. Some juveniles do disperse off our study areas, and would not be included as survivors in our analysis. If this dispersal were skewing our estimates of survival, we would expect to see lower apparent survival of juveniles born at the edge of the study area compared to those born in the core. This is not the case: juveniles born on the edge have equivalent survival to those born in the core (26\% vs. 27\%; McAdam et al., 2007). However, we cannot completely discern between mortality and long-distance dispersal as some long-distance dispersal has been documented (A.R. Martinig, unpubl. data).

We used Tomahawk traps (Tomahawk Live Trap Co.) baited with peanut butter on each individual's territory or that of its mother to trap them. When handled for the first time, we gave each individual numbered ear tags (Monel \#1; 5 digits) with a unique combination of coloured wires or pipe cleaners to facilitate future identification without handling. We recorded body mass, sex and reproductive status at each capture. We radio-collared reproductive females (model PD-2C, 4 g; Holohil Systems Limited) to find nests. Females typically give birth to three pups (range: 1-7; Humphries \& Boutin, 2000) in the spring (median birth date: 23 April). We removed juveniles from the nest after birth, and a second time at $\sim 25$ days old, to record litter size, pup mass and sex, and to tag them. We calculated growth rate $(\mathrm{g} /$ day) as the linear increase in mass between the nest entries. We calculated growth rates only for juveniles that weighed less than $50 \mathrm{~g}$ at the first nest entry and less than $100 \mathrm{~g}$ at the second nest entry (to ensure approximate linearity of the growth curve; McAdam $\&$ Boutin, 2003), and only for juveniles where the two weight measures were $>5$ days apart. Juvenile red squirrels emerge from the nest around 42-50 days old (A.R. Martinig, unpubl. data) and wean around 70 days (Larsen \& Boutin, 1994). We considered juveniles surviving to the spring following the year of their birth to have recruited into the population, as we have done previously (McAdam \& Boutin, 2003). This research was approved by the University of Guelph Animal Care Committee (AUP 1807), the University of Alberta Animal Care and Use Committee for Biosciences, and the University of Michigan Institutional Animal Care and Use Committee (PRO00007805).

\section{2 | Predator and temperature data collection}

Our available temperature and predator data are annual, regional measures, so for this analysis we considered all juveniles born in the same year to be experiencing the same conditions. We obtained monthly temperature records from Environment Canada's online historical weather database for the Haines Junction weather station (Climate ID $2100630,60.77^{\circ} \mathrm{N}, 137.57^{\circ} \mathrm{W}$ ), approximately $35 \mathrm{~km} \mathrm{SE}$ of our study area. We used mean temperature overwinter, as we expected that climate would primarily influence overwinter survival by increasing thermoregulatory costs as opposed to extreme weather events or precipitation. We averaged the monthly temperatures from October of a juvenile's birth year to the following March to obtain an annual average winter temperature. 
We considered potential mammalian predators: mustelids (shorttailed weasel Mustela erminea, least weasel M. nivalis and marten Martes americana) and lynx. We obtained abundance data for predators and their alternate prey from population monitoring in our region, first as part of the Kluane Boreal Forest Ecosystem Project (Krebs, 2001), and after 1996 as part of the Community Ecological Monitoring Program (data available at http://www.zoology.ubc. $\mathrm{ca} / \sim \mathrm{krebs} /$ kluane.html). Repeated snow track counts along set transects during winter provided an index of species abundance as the mean number of snow tracks per $100 \mathrm{~km}$ of transect for each year. We do not estimate population sizes from these track counts, but instead use them as indices for relative comparisons between years. As the monitoring protocol was consistent throughout the study, we do not expect a directional bias in these estimates. We used the sum of short-tailed weasel, least weasel and marten tracks as an index of the total mustelid abundance for each year. The population densities of snowshoe hares Lepus americanus and red-backed voles Myodes rutilis were estimated with live trapping and mark-recapture (Krebs, Boonstra, Kenney, \& Gilbert, 2018), providing measures of alternate prey availability for these predators. We chose these combinations as lynx are known snowshoe hare specialists (O'Donoghue, Boutin, Krebs, Murray, \& Hofer, 1998), while weasels (the majority of the mustelids) are known vole specialists (Boonstra \& Krebs, 2006), and both populations follow the cycles of their preferred prey (Boutin et al., 1995). While birds of prey such as goshawks and great horned owls Bubo virginianus are known predators of red squirrels (Larsen \& Boutin, 1994), we were not able to include them in our analysis because density indices were not available. Such birds of prey primarily prey on snowshoe hares, and so their populations typically track those of snowshoe hares, as lynx populations do (Boutin et al., 1995). Therefore, the effect of lynx abundance may somewhat represent the overall effect of snowshoe hare predators on red squirrels.

\subsection{Statistical analyses of survival}

We used a binomial mixed effects model to test how predation and temperature interacted with autumn territory ownership to affect juvenile survival overwinter. From 1989 to 2015, our analysis considered whether those juveniles that survived to the beginning of autumn ( $n=1,305$ squirrels) were still alive the following spring.

For our main question-does territory ownership mediate how predators and climate affect overwinter survival-we included territory ownership in autumn as a binary predictor with temperature and predator abundance as numeric predictors, and fit interactions between autumn ownership and each of temperature, lynx and mustelid abundances separately. We included separate interactions between the abundance of lynx and snowshoe hares, and mustelids and voles, so the effect of predators on red squirrels depended on the availability of preferred prey. Temperature and species abundances were standardized as z-scores across years. This improves model convergence and interpretability of regression coefficients
(Schielzeth, 2010). We included random effects of litter identity and year to account for variation in survival due to sibling and maternal interactions, as well as otherwise unaccounted for annual variation.

We also included several factors previously shown to affect juvenile survival in our system (Descamps et al., 2008): these included adult population density (number of adults within a set 38 ha area that remained consistent over the entire study period), white spruce cone availability (annual index of cones produced on a consistent subset of trees on each study area; see LaMontagne, Peters, \& Boutin, 2005), a fixed effect of study area to account for any differences between the two study areas, birth date, growth rate and sex. Growth rate, birth date, adult population density and cone availability were standardized as $z$-scores for each study area in each year.

We also fitted a separate model with the interactions of juvenile birth date and growth rate with predators and temperature, to determine whether these traits influence these sources of mortality. We used a different model in order to avoid overfitting due to too many terms in our initial model. We present these results in the supporting information (Table S1); we found no evidence of predator abundance or temperature overwinter acting as agents of selection on either of these traits.

We have provided the correlations between predictor variables (Table S2) and variance inflation factors (Table 2). We note here that correlations between predictor variables and the resulting larger standard error for an estimate are not necessarily problematic (see Morrissey \& Ruxton, 2018). We interpret each of our estimates in light of the fact that they are estimated given the other effects in the model. As each continuous variable was mean centred, estimates are effectively given for the mean value of all other variables.

We conducted all statistical analyses using $\mathrm{R}$ version 3.3.3 (R Core Team, 2017), with the packages LME4 (version 1.1-19; Bates, Maechler, Bolker, \& Walker, 2015) and LMERTEST (version 2.0-33; Kuznetsova, Brockhoff, \& Christensen, 2017). Reported estimates are $M \pm S E$.

\section{3 | RESULTS}

\section{1 | Overwinter survival}

We found that an average of $60 \%$ of juveniles alive in autumn ( $n=1,305)$ survived to spring, but this was highly variable $(21.4 \%$ 94.1\%; Table 1). Juvenile overwinter survival was higher with increased cone availability ( $\beta=0.38 \pm 0.11, z=3.45, p<0.001$; Table 2$)$ and years of lower adult population density $(\beta=-0.69 \pm 0.15, z=-4.45$, $p<0.001)$. Juvenile females were more likely to survive overwinter than males $(\beta=0.49 \pm 0.16, z=3.1, p=0.002)$, as were juveniles with higher growth rates $(\beta=0.22 \pm 0.10, z=2.13, p=0.033$ ). Birth date had no effect on overwinter survival $(\beta=-0.01 \pm 0.09$, $z=-0.08, p=0.936)$, nor were there any differences between study areas $(\beta=0.19 \pm 0.18, z=1.06, p=0.289)$. The random effect of litter 
TABLE 1 Probability of overwinter survival for juvenile red squirrels alive in August 1989-2015 ( $n=1,305)$, with adult density for each year (individuals/ha), number of juveniles alive in autumn (cohort size) and proportion of juveniles with territories in autumn (autumn territory owners)

\begin{tabular}{|c|c|c|c|c|}
\hline Year & $\begin{array}{l}\text { Adult } \\
\text { population } \\
\text { density } \\
\text { (individuals/ } \\
\text { ha) }\end{array}$ & $\begin{array}{l}\text { Autumn } \\
\text { cohort } \\
\text { size }\end{array}$ & $\begin{array}{l}\text { Autumn } \\
\text { territory } \\
\text { owners (\%) }\end{array}$ & $\begin{array}{l}\text { Juvenile } \\
\text { survival (\%) }\end{array}$ \\
\hline 1989 & 1.25 & 6 & 100 & 66.7 \\
\hline 1990 & 1.30 & 13 & 76.9 & 61.5 \\
\hline 1991 & 1.18 & 28 & 82.1 & 85.7 \\
\hline 1992 & 1.31 & 46 & 32.6 & 30.4 \\
\hline 1993 & 1.23 & 121 & 59.5 & 71.1 \\
\hline 1994 & 2.20 & 28 & 89.3 & 21.4 \\
\hline 1995 & 1.60 & 75 & 84.0 & 82.7 \\
\hline 1996 & 1.88 & 15 & 80.0 & 60.0 \\
\hline 1997 & 1.86 & 51 & 88.2 & 94.1 \\
\hline 1998 & 2.14 & 78 & 74.4 & 82.1 \\
\hline 1999 & 3.93 & 25 & 64.0 & 36.0 \\
\hline 2000 & 2.56 & 24 & 62.5 & 58.3 \\
\hline 2001 & 1.84 & 56 & 60.7 & 51.8 \\
\hline 2002 & 1.63 & 49 & 67.4 & 51.0 \\
\hline 2003 & 1.22 & 34 & 88.2 & 70.6 \\
\hline 2004 & 1.02 & 44 & 61.4 & 61.4 \\
\hline 2005 & 1.05 & 98 & 38.8 & 66.3 \\
\hline 2006 & 2.02 & 47 & 74.5 & 46.8 \\
\hline 2007 & 1.40 & 72 & 54.1 & 55.6 \\
\hline 2008 & 1.40 & 30 & 86.7 & 43.3 \\
\hline 2009 & 0.94 & 44 & 59.1 & 50.0 \\
\hline 2010 & 0.73 & 100 & 35.0 & 66.0 \\
\hline 2011 & 1.75 & 32 & 87.5 & 81.3 \\
\hline 2012 & 1.86 & 50 & 46.0 & 46.0 \\
\hline 2013 & 1.73 & 54 & 63.0 & 63.0 \\
\hline 2014 & 1.57 & 150 & 71.3 & 71.3 \\
\hline 2015 & 3.15 & 18 & 44.4 & 44.4 \\
\hline Average $\pm S E$ & $1.69 \pm 0.13$ & $51 \pm 6.6$ & $65.4 \pm 4.1$ & $60.0 \pm 3.4$ \\
\hline
\end{tabular}

identity explained a significant amount of variation $\left(\sigma^{2}=0.665\right.$; likelihood ratio test $\chi^{2}=7.867, d f=20, p=0.005$ ), but the random year effect did not contribute to the model $\left(\sigma^{2}<0.001\right.$; likelihood ratio test $\chi^{2}=0, d f=20, p=1$ ) given the inclusion of litter identity.

\section{2 | Territory ownership and overwinter survival}

About $61 \%$ of juveniles alive in autumn owned a territory, and territory owners were more likely (79\%) to survive overwinter than those who did not own a territory (33\%; $\beta=2.78 \pm 0.23, z=12.06, p<0.001$ ). Increased lynx abundance was associated with a decrease in the
TABLE 2 Mixed effects binomial model of juveniles red squirrel overwinter survival ( $n=1,305)$, testing whether territory ownership by autumn mediates effects of predators and temperature on overwinter survival, including random effects of litter ID and year (conditional $R^{2}=0.44$ ). Variance inflation factor $(\mathrm{VIF})$, a measure of collinearity between variables, was calculated for each predictor.

Estimates of predator and temperature effects indicate effects for the reference category of juveniles without territories in autumn

\begin{tabular}{|c|c|c|c|c|}
\hline Term & Estimate $\pm S E$ & $z$ & $p$ & VIF \\
\hline Std. density & $-0.69 \pm 0.15$ & -4.45 & $<0.001$ & 1.96 \\
\hline Std. cones & $0.38 \pm 0.11$ & 3.45 & $<0.001$ & 1.76 \\
\hline Std. growth rate & $0.22 \pm 0.10$ & 2.13 & 0.033 & 1.02 \\
\hline Std. birth date & $-0.01 \pm 0.09$ & -0.08 & 0.936 & 1.16 \\
\hline Grid (SU) & $0.19 \pm 0.18$ & 1.06 & 0.289 & 1.17 \\
\hline Sex (male) & $-0.49 \pm 0.16$ & -3.1 & 0.002 & 1.03 \\
\hline Autumn owner (yes) & $2.78 \pm 0.23$ & 12.06 & $<0.001$ & 1.70 \\
\hline $\begin{array}{l}\text { Std. lynx } \\
\text { (non-owners) }\end{array}$ & $-0.68 \pm 0.28$ & -2.41 & 0.016 & 4.22 \\
\hline Std. hares & $0.40 \pm 0.20$ & 1.99 & 0.046 & 3.71 \\
\hline $\begin{array}{l}\text { Std. mustelid } \\
\text { (non-owners) }\end{array}$ & $-0.38 \pm 0.14$ & -2.7 & 0.007 & 2.71 \\
\hline Std. voles & $-0.59 \pm 0.13$ & -4.57 & $<0.001$ & 2.30 \\
\hline $\begin{array}{l}\text { Std. temperature } \\
\text { (non-owners) }\end{array}$ & $-0.35 \pm 0.18$ & -1.99 & 0.047 & 2.16 \\
\hline Std. Iynx: Std. hares & $0.12 \pm 0.09$ & 1.32 & 0.187 & 1.64 \\
\hline $\begin{array}{l}\text { Std. mustelid: Std. } \\
\text { voles }\end{array}$ & $0.14 \pm 0.11$ & 1.27 & 0.203 & 2.26 \\
\hline $\begin{array}{l}\text { Autumn owner (yes): } \\
\text { Std. Iynx }\end{array}$ & $0.99 \pm 0.23$ & 4.22 & $<0.001$ & 2.26 \\
\hline $\begin{array}{l}\text { Autumn owner (yes): } \\
\text { Std. mustelid }\end{array}$ & $0.31 \pm 0.18$ & 1.75 & 0.080 & 2.03 \\
\hline $\begin{array}{l}\text { Autumn owner (yes): } \\
\text { Std. temperature }\end{array}$ & $1.11 \pm 0.21$ & 5.31 & $<0.001$ & 1.62 \\
\hline Random effects & Variance & & & \\
\hline Litter ID & 0.665 & & & \\
\hline Year & 0.000 & & & \\
\hline
\end{tabular}

overwinter survival of juveniles without territories $(\beta=-0.68 \pm 0.28$, $z=-2.41, p=0.016$ ), but had no effect on the overwinter survival of juveniles that held territories by autumn (interaction between Iynx abundance and territory ownership, $\beta=0.99 \pm 0.23, z=4.22$, $p<0.001$; Figure 1). Mustelid abundance was somewhat more strongly (interaction between mustelid abundance and territory ownership: $\beta=0.31 \pm 0.18, z=1.75, p=0.080$ ) associated with lower winter survival for juveniles without a territory $(\beta=-0.38 \pm 0.14$, $z=-2.70, p=0.007$ ) than for juveniles that held territories by autumn ( $\beta=-0.07 \pm 0.14, z=-0.49, p=0.624$; Figure 2 ). The effects of predators on juvenile survival overwinter were not associated with the abundance of alternate prey (lynx by hare interaction, $p=0.187$; mustelid by vole interaction, $p=0.203)$, but both the hare $(\beta=0.40 \pm 0.20$, $z=1.99, p=0.046)$ and vole $(\beta=-0.59 \pm 0.13, z=-4.57, p<0.001)$ abundances influenced juvenile overwinter survival. 


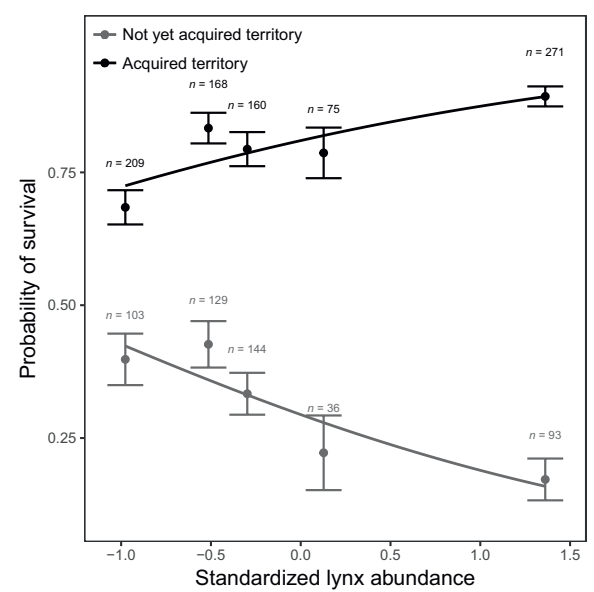

FIGURE 1 Overwinter survival of juvenile North American red squirrels Tamiasciurus hudsonicus $(n=1,305)$ that had or had not acquired a territory by autumn. Juveniles without territories had lower survival when lynx Lynx canadensis were abundant (not yet acquired territory: $\beta=-0.68 \pm 0.28, z=-2.41, p=0.016$ ), whereas the survival of juveniles with territories was unaffected by lynx abundance (acquired territory: $\beta=0.31 \pm 0.21, z=1.49$, $p=0.14$; interaction $\beta:=0.99 \pm 0.23, z=4.22, p<0.001)$. Points represent mean survival $\pm S E$ for each quintile of standardized lynx abundance estimates. These points are shown only for illustrative purposes; lynx abundance was analysed as a continuous variable in all analyses

Temperature had opposing effects on survival for juveniles with and without territories by autumn (Figure 3). Juveniles without territories by autumn were less likely to survive warm winters ( $\beta=-0.35 \pm 0.18, z=-1.99, p=0.047)$, but this effect reversed for autumn territory owners (interaction $\beta=1.11 \pm 0.21, z=5.31$, $p<0.001$ ), which were more likely to survive warm winters $(\beta=0.76 \pm 0.13, z=5.31, p<0.001)$.

\section{4 | DISCUSSION}

Juvenile red squirrels that acquired territories by autumn were far more likely to survive the winter than those that had not yet acquired a territory. Average survival of juveniles that acquired territories before the start of cone caching (79\%) was comparable to survival of early life adults in this population (80\%; McAdam et al., 2007). Juveniles without territories by autumn had much lower survival (33\%). Although it is possible that juveniles without a territory had in fact moved off our study area, we cannot test this with our available dataset. However, the effect of long-distance dispersal is expected to be small as survival is equal between juveniles originating from the centre of the study area and those at the edge (Kerr, Boutin, LaMontagne, McAdam, \& Humphries, 2007).

Territory ownership also affected how susceptible juveniles were to predators and weather overwinter. Juveniles without territories by autumn were more susceptible to predators than those that had already settled. Territory ownership provides access to arboreal nests, tunnels and increased familiarity with the local habitat (Clarke

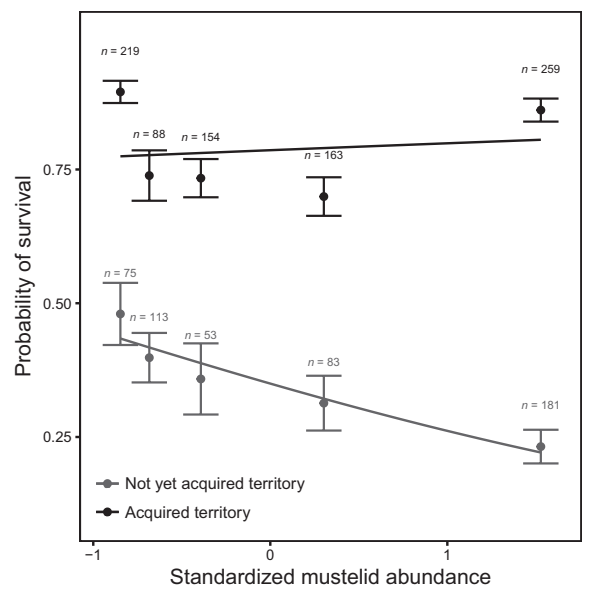

FIGURE 2 Overwinter survival of juvenile North American red squirrels Tamiasciurus hudsonicus $(n=1,305)$ that had or had not acquired a territory by autumn was lower when mustelids (shorttailed weasel Mustela erminea, least weasel M. nivalis and marten Martes americana) were abundant. Juveniles without territories by autumn were somewhat more affected by mustelid abundance (not yet acquired territory: $\beta=-0.38 \pm 0.14, z=-2.70, p=0.007$ ) than territory owners (acquired territory: $\beta=-0.07 \pm 0.14, z=-0.49$, $p=0.624$; interaction $\beta=0.31 \pm 0.18, z=1.75, p=0.080)$. Points represent mean survival $\pm S E$ for each quintile of standardized mustelid abundance estimates. These points are shown only for illustrative purposes; mustelid abundance was analysed as a continuous variable in all analyses

et al., 1993). Juveniles without territories by autumn may be travelling more through potentially high-risk environments as they forage for food or search for territories overwinter, thereby increasing their vulnerability to predators (Garrett \& Franklin, 1988; Metzgar, 1967). Higher rates of litter loss in red squirrels during years of high mustelid abundance (Studd et al., 2015) suggest that mustelids may enter red squirrel nests (and likely tunnels), whereas lynx cannot access these structures. This may explain why the relationship between mustelid abundance and overwinter survival was not as strongly influenced by territory acquisition as was the relationship between lynx abundance and survival.

Survival of juveniles without a territory was higher in colder winters, with the opposite being true for juveniles holding a territory by autumn. We predicted that cold winters would lead to lower overwinter survival of territory owners, and we expected this to be magnified for non-territory owners, not reversed. There are some situations in which colder winters lead to higher survival, such as in hibernating species (bats Chalinolobus tuberculatus; Pryde, O'Donnell, \& Barker, 2005; jumping mice Zapus hudsonicus preblei; Schorr et al., 2009) where this leads to less frequent arousal from hibernation (Humphries, Thomas, \& Speakman, 2002). Red squirrels are non-hibernating, so this mechanism cannot explain why nonterritory owners would benefit from colder winters.

We can suggest two alternative but non-mutually exclusive explanations for why juveniles that acquired a territory late would have higher survival over colder winters. First, in colder years the incidence of nest sharing among non-territory owners might be higher. Nest 


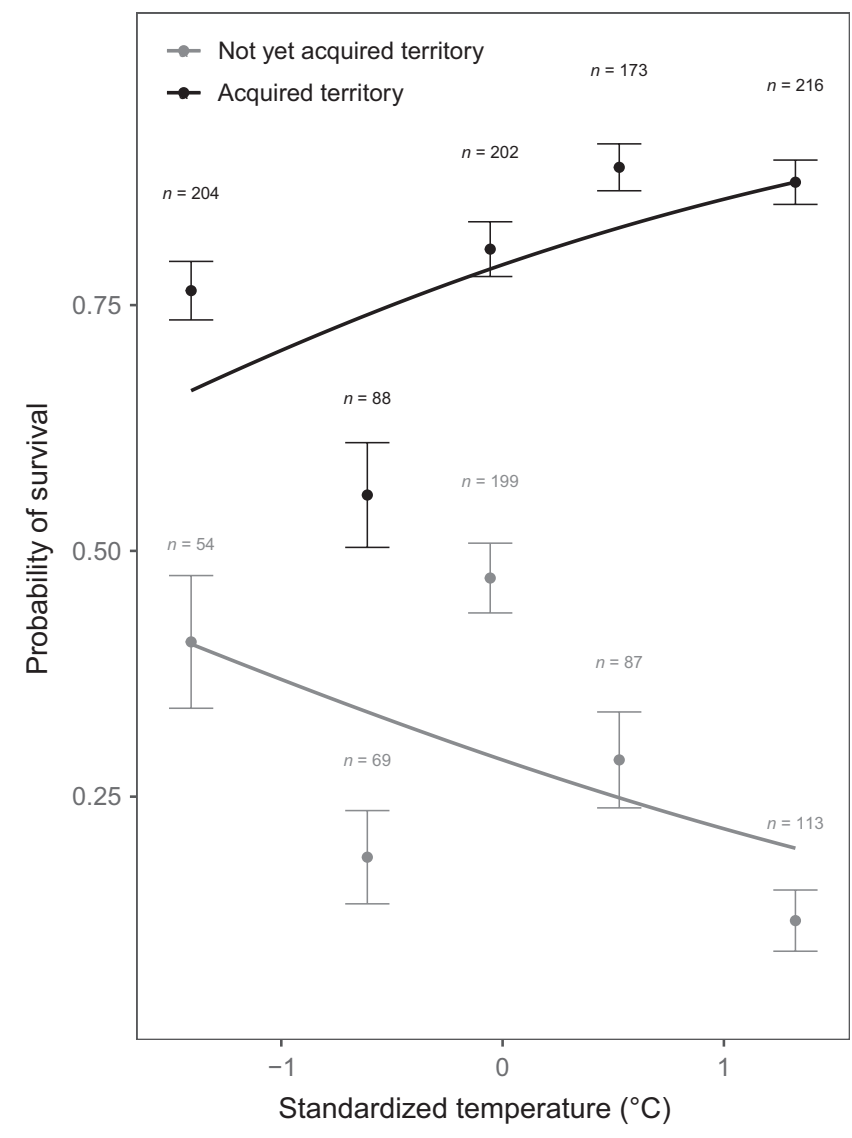

FIGURE 3 Overwinter survival of juvenile North American red squirrels Tamiasciurus hudsonicus $(n=1,305)$ that had or had not acquired a territory by autumn. Autumn territory owners survived better in warmer years (acquired territory: $\beta=0.76 \pm 0.13$, $z=5.87, p<0.001$ ), whereas warmer winters decreased survival of juveniles without territories at this time (not yet acquired territory: $\beta=-0.35 \pm 0.18, z=-1.99, p=0.047$; interaction $\beta=1.11 \pm 0.21$, $z=5.31, p<0.001)$. Points represent mean survival $\pm S E$ for each quintile of standardized winter temperatures. These points are shown only for illustrative purposes; winter temperature was analysed as a continuous variable in all analyses

sharing, typically between kin, occurs in $19 \%$ of female territory owners in this system, and is more common in colder winters (Williams et al., 2013). We speculate that juveniles without territories in autumn may be more likely to share nests with fellow non-territory owners or their mothers (Larsen \& Boutin, 1994; A.R. Martinig, pers. obs.), and this may improve their survival relative to juveniles with territories in autumn. Second, the higher mortality of juvenile territory owners in colder winters creates vacancies, which may allow juveniles without territories prior to autumn a greater opportunity to claim a territory with cached food, enhancing survival (Dunham, Warner, \& Lawson, 1995). This would give them relatively improved survival compared to warmer years where fewer juvenile territory owners would die. Which, if either, of these mechanisms accounts for the differential effect of winter temperature remains to be tested.

We found both lynx and mustelid abundances were negatively associated with juvenile overwinter survival. Previous work found that predation does not exert a strong influence on red squirrel populations in the boreal forest (Boonstra, Boutin, et al., 2001). However, in this study, the relative effects of annual lynx and mustelid abundance on overwinter juvenile survival (-0.68 and -0.32 for those without territories by autumn) were comparable in strength to the effect of cone availability (0.38), which is the primary driver of red squirrel population dynamics (LaMontagne et al., 2013). The relatively strong effects of predator abundances on overwinter survival in this study might appear contradictory to previous findings, but two distinctions can be made. First, overall population size and individual probability of survival are not directly comparable. While red squirrel population size may be dictated by the availability of food and territories, predation could still affect which individuals survive ('compensatory predation'; Errington, 1946). Second, this study was concerned with overwinter survival of only juveniles, and predator abundances had the strongest effect on the $39 \%$ of juveniles that did not have territories by autumn. The probability of survival of these juveniles is already low, so variation in survival in this subset is not likely to have a large impact on the total population size.

We predicted that the effects of lynx and mustelid abundances on juvenile survival would be mediated by the availability of their alternate prey, but we did not find any detectable two-way interactions of either predator-prey pairing on red squirrel survival. One potential explanation for this could be that predator populations closely track their prey. The positive correlation between lynx and snowshoe hare abundances (0.73) makes the detection of an interaction difficult. For example, there were few years in our dataset with high predator and low prey abundances with which to evaluate these interactions. Additionally, although lynx switch from snowshoe hares to red squirrels when the former are rare (O'Donoghue, Boutin, Krebs, Zuleta, et al., 1998), lynx and mustelids may predate on juvenile red squirrels opportunistically if juveniles, particularly those without territories by autumn, are more susceptible to predation regardless of alternate prey availability.

We did not anticipate that the abundance of voles and hares would be associated with winter survival of juvenile red squirrels. High snowshoe hare abundance was associated with increased juvenile survival overwinter, while years with high vole abundances had lower juvenile survival. Red squirrels will opportunistically predate on snowshoe hare leverets in the spring and summer (O'Donoghue, 1994), but this additional food source should not have a strong effect overwinter. Voles are not in strong competition with juveniles for resources, given red squirrels access arboreal food sources unavailable to voles, and red-backed voles are broad omnivores, feeding on vegetation, fungi and arthropods (Boonstra, Krebs, Gilbert, \& Schweiger, 2001). The effect of snowshoe hare abundance on juvenile winter survival could also be a statistical artefact of the correlation between lynx and hare abundance. Vole and mustelid abundances are weakly correlated (0.27), so it is less likely that this explanation holds for the negative affect of vole abundance on red squirrel overwinter survival. These species' abundances may also covary with another factor that influences juvenile survival not included in our analysis, but what this factor might be remains unclear. 
In our survival model, juveniles with higher growth rates were more likely to survive to spring, but birth date had no effect. Previous work in this population has observed strong selection on both birth date and growth rate in annual survival of juveniles (Dantzer et al., 2013; Fisher et al., 2017; McAdam \& Boutin, 2003; Williams, Lane, Humphries, McAdam, \& Boutin, 2014). In preliminary models not including territory ownership, there was a detectable effect of birth date on winter survival. Once accounting for territory ownership, birth date stopped being important. This implies that early born juveniles are likely to acquire a territory sooner, but there are no further benefits of birth date for survival overwinter. Both earlier birth dates and higher growth rates are thought to be beneficial in territory acquisition, but there was still an effect of growth rate on overwinter survival after accounting for territory ownership (Table 2). Furthermore, larger juveniles in the autumn are more likely to survive to spring (Larivée et al., 2010). Among juveniles for which we have body mass measurements in autumn $(n=757)$, juveniles with higher relative growth rates were $\operatorname{larger}(\beta=7.95 \pm 1.61$, $t=4.93, p<0.001$ ), but earlier birth dates also influenced body mass in autumn $(\beta=-8.89 \pm 1.25, t=-7.11, p<0.001)$ so this does not explain why growth rate provides further benefits overwinter but birth date does not. Presumably, growth rate may be associated with other life-history and behavioural traits (Biro \& Stamps, 2008; Réale et al., 2010; Stamps, 2007) that could affect winter survival.

\section{5 | CONCLUSIONS}

We have identified how the timing of a life-history event-territory acquisition-influences juvenile overwinter survival, and how it mediates biotic and abiotic factors that influence survival. This gives us insight into how one trait can affect the opportunity for selection on others, and therefore the functional links between phenotypes and fitness. We encourage more researchers to study life stages such as the juvenile period, when survival is highly variable and so the opportunity for selection is high, to better understand how selection acts on traits in populations. As this study was primarily concerned with overwinter dynamics, investigations of juveniles during their search for territories and before settlement, and which traits or conditions are associated with territorial acquisition would be informative in further explaining the mechanisms behind some of the patterns we observed.

\section{ACKNOWLEDGEMENTS}

We acknowledge that the lands on which we have conducted our research for the past 30 years are within the traditional territory of the Champagne and Aishihik First Nations. We thank Agnes MacDonald for providing access to her trapline. We thank the people who have been involved in data collection over the years within the Kluane Red Squirrel Project, and many thanks to Charles Krebs and the Kluane Boreal Forest Ecosystem Project and Community Ecological Monitoring Program for making their data freely available to the public. The Natural Sciences and Engineering Council of Canada, the National Science Foundation and the Northern Scientific Training
Program provided research support. We have no conflict of interest. This is paper number 107 of the Kluane Red Squirrel Project.

\section{AUTHORS' CONTRIBUTIONS}

J.G.H. and D.N.F. conceived the ideas and conducted the analyses; J.G.H., D.N.F. and A.R.M. led the writing of the manuscript; S.B., B.D., J.E.L. and A.G.M. managed long-term data collection and revised initial drafts and analyses. All the authors contributed critically to the drafts and gave final approval for publication.

\section{DATA AVAILABILITY STATEMENT}

Data used to evaluate juvenile overwinter survival, along with code to recreate analyses and figures, are available on Dryad Digital Repository: https://doi.org/10.5061/dryad.q2bvq83g0 (Hendrix et al., 2020). Note the dataset is embargoed for 1 year from the date of publication.

\section{ORCID}

Jack G. Hendrix iD https://orcid.org/0000-0002-8606-1239

David N. Fisher (iD https://orcid.org/0000-0002-4444-4450

April Robin Martinig iD https://orcid.org/0000-0002-0972-6903

Stan Boutin iD https://orcid.org/0000-0001-6317-038X

Ben Dantzer (iD https://orcid.org/0000-0002-3058-265X

Andrew G. McAdam iD https://orcid.org/0000-0001-7323-2572

\section{REFERENCES}

Archibald, D. W., Fletcher, Q. E., Boutin, S., McAdam, A. G., Speakman, J. R., \& Humphries, M. M. (2013). Sex-specific hoarding behavior in North American red squirrels (Tamiasciurus hudsonicus). Journal of Mammalogy, 94(4), 761-770. https://doi.org/10.1644/12-MAMM-A-213.1

Bates, D., Maechler, M., Bolker, B., \& Walker, S. (2015). Fitting linear mixed-effects models using Ime4. Journal of Statistical Software, 67, 1-8. https://doi.org/10.18637/jss.v067.i01

Berteaux, D., \& Boutin, S. (2000). Breeding dispersal in female North American red squirrels. Ecology, 81(5), 1311-1326. https://doi. org/10.1890/0012-9658(2000)081[1311:BDIFNA]2.0.CO;2

Biro, P. A., \& Stamps, J. A. (2008). Are animal personality traits linked to life-history productivity? Trends in Ecology \& Evolution, 23(7), 361368. https://doi.org/10.1016/j.tree.2008.04.003

Boonstra, R., Boutin, S., Byrom, A., Karels, T. I. M., Hubbs, A., StuartSmith, K., ... Antpoehler, S. (2001). The role of red squirrels and arctic ground squirrels. In C. J. Krebs, S. Boutin, \& R. Boonstra (Eds.), Ecosystem dynamics of the boreal forest: The Kluane project (pp. 179215). New York, NY: Oxford University Press.

Boonstra, R., \& Krebs, C. J. (2006). Population limitation of the northern red-backed vole in the boreal forests of northern Canada. Journal of Animal Ecology, 75(6), 1269-1284. https://doi.org/ 10.1111/j.1365-2656.2006.01149.x

Boonstra, R., Krebs, C. J., Gilbert, B., \& Schweiger, S. (2001). Voles and mice. In C. J. Krebs, S. Boutin, \& R. Boonstra (Eds.), Ecosystem dynamics of the boreal forest: The Kluane project (pp. 215-239). New York, NY: Oxford University Press.

Boutin, S., Krebs, C. J., Boonstra, R., Dale, M. R. T., Hannon, S. J., Martin, K., ... Schweiger, S. (1995). Population changes of the vertebrate community during a snowshoe hare cycle in Canada's boreal forest. Oikos, 74(1), 69. https://doi.org/10.2307/3545676

Carpenter, F. L. (1987). Food abundance and territoriality: To defend or not to defend? Integrative and Comparative Biology, 27(2), 387-399. https://doi.org/10.1093/icb/27.2.387 
Clarke, M. F., Burke, K., Lair, H., Pocklington, R., Clarke, M. F., Burke, K., ... Robert, L. (1993). Familiarity affects escape behaviour of the Eastern chipmunk, Tamias striatus. Oikos, 66(3), 533-537. https://doi. org/10.2307/3544949

Cooper, E. B., Taylor, R. W., Kelley, A. D., Martinig, A. R., Boutin, S., Humphries, M. M., ... McAdam, A. G. (2017). Personality is correlated with natal dispersal in North American red squirrels (Tamiasciurus hudsonicus). Behaviour, 154, 939-961. https://doi.org/10.1163/15685 39X-00003450

Cowlishaw, G. (1997). Refuge use and predation risk in a desert baboon population. Animal Behaviour, 54(2), 241-253. https://doi. org/10.1006/anbe.1996.0466

Dantzer, B., Newman, A. E. M., Boonstra, R., Palme, R., Boutin, S., Humphries, M. M., \& McAdam, A. G. (2013). Density triggers maternal hormones that increase adaptive offspring growth in a wild mammal. Science, 340(6137), 1215-1217. https://doi.org/10.1126/ science. 1235765

Descamps, S., Boutin, S., Berteaux, D., \& Gaillard, J.-M. (2008). Agespecific variation in survival, reproductive success and offspring quality in red squirrels: Evidence of senescence. Oikos, 117(9), 14061416. https://doi.org/10.1111/j.0030-1299.2008.16545.x

Dunham, M. L., Warner, R. R., \& Lawson, J. W. (1995). The dynamics of territory acquisition: A model of two coexisting strategies. Theoretical Population Biology, 47, 347-364. https://doi.org/10.1006/ tpbi.1995.1016

Errington, P. L. (1946). Predation and vertebrate populations. The Quarterly Review of Biology, 21(2), 144-177. https://doi.org/10.1086/395220

Everett, R. A., \& Ruiz, G. M. (1993). Coarse woody debris as a refuge from predation in aquatic communities: An experimental test. Oecologia, 93(4), 475-486. https://doi.org/10.1007/BF00328954

Ferguson, G. W., \& Fox, S. F. (1984). Annual variation of survival advantage of large juvenile side-blotched lizards, Uta stansburiana: Its causes and evolutionary significance. Evolution, 38(2), 342-349. https://doi.org/10.1111/j.1558-5646.1984.tb00292.x

Fisher, D. N., Boutin, S., Dantzer, B., Humphries, M. M., Lane, J. E., \& McAdam, A. G. (2017). Multilevel and sex-specific selection on competitive traits in North American red squirrels. Evolution, 71(7), 18411854. https://doi.org/10.1111/evo.13270

Fisher, D. N., Haines, J. A., Boutin, S., Dantzer, B., Lane, J. E., Coltman, D. W., \& McAdam, A. G. (2019). Indirect effects on fitness between individuals that have never met via an extended phenotype. Ecology Letters, 22(4), 697-706. https://doi.org/10.1111/ele.13230

Fletcher, Q. E., Boutin, S., Lane, J. E., LaMontagne, J. M., McAdam, A. G., Krebs, C. J., \& Humphries, M. M. (2010). The functional response of a hoarding seed predator to mast seeding. Ecology, 91(9), 2673-2683. https://doi.org/10.1890/09-1816.1

Fletcher, Q. E., Landry-Cuerrier, M., Boutin, S., McAdam, A. G., Speakman, J. R., \& Humphries, M. M. (2013). Reproductive timing and reliance on hoarded capital resources by lactating red squirrels. Oecologia, 173(4), 1203-1215. https://doi.org/10.1007/s00442-013-2699-3

Fuller, W. A., Stebbins, L. L., \& Dyke, G. R. (1969). Overwintering of small mammals near Great Slave Lake Northern Canada. Arctic, 22(1), 34-55. https://doi.org/10.2307/40507757

Gaillard, J. M., Festa-Bianchet, M., \& Yoccoz, N. G. (1998). Population dynamics of large herbivores: Variable recruitment with constant adult survival. Trends in Ecology and Evolution, 13(2), 58-63. https:// doi.org/10.1016/S0169-5347(97)01237-8

Gaillard, J.-M., Festa-Bianchet, M., Yoccoz, N. G., Loison, A., \& Toïgo, C. (2000). Temporal variation in fitness components and population dynamics of large herbivores. Annual Review of Ecology and Systematics, 31(1), 367-393. https://doi.org/10.1146/annurev.ecolsys.31.1.367

Galef, B. G. (1981). The ecology of weaning: Parasitism and the achievement of independence by altricial mammals. In D. J. Gubernick \& P. H. Klopfer (Eds.), Parental care in mammals (pp. 211-241). Boston, MA: Springer. https://doi.org/10.1007/978-1-4613-3150-6_6
Garrett, M. G., \& Franklin, W. L. (1988). Behavioral ecology of dispersal in the black-tailed prairie dog. Journal of Mammalogy, 69(2), 236-250. https://doi.org/10.2307/1381375

Goheen, J. R., \& Swihart, R. K. (2005). Resource selection and predation of North American red squirrels in deciduous forest fragments. Journal of Mammalogy, 86(1), 22-28. https://doi.org/ 10.1644/1545-1542(2005)086<0022:rsapon>2.0.co;2

Greenwood, P. J., \& Harvey, P. H. (1982). The natal and breeding dispersal of birds. Annual Review of Ecology and Systematics, 13, 1-21. https:// doi.org/10.1146/annurev.es.13.110182.000245

Haines, J. A., Coltman, D. W., Dantzer, B., Gorrell, J. C., Humphries, M. M., Lane, J. E., ... Boutin, S. (2018). Sexually selected infanticide by male red squirrels in advance of a mast year. Ecology, 99(5), 12421244. https://doi.org/10.1002/ecy.2158

Hendrix, J. G., Fisher, D. N., Martinig, A. R., Boutin, S., Dantzer, B., Lane, J. E., \& McAdam, A. G. (2020). Data from: Territory acquisition mediates the influence of predators and climate on juvenile red squirrel survival. Dryad Digital Repository, https://doi.org/10.5061/dryad. q2bvq83g0

Humphries, M. M., \& Boutin, S. (2000). The determinants of optimal litter size in free-ranging red squirrels. Ecology, 81(10), 2867-2877. https:// doi.org/10.1890/0012-9658(2000)081[2867:TDOOLS]2.0.CO;2

Humphries, M. M., Thomas, D. W., \& Speakman, J. R. (2002). Climatemediated energetic constraints on the distribution of hibernating mammals. Nature, 418(6895), 313-316. https://doi.org/10.1038/ nature00828

Jackson, D. M., Trayhurn, P., \& Speakman, J. R. (2001). Associations between energetics and over-winter survival in the short-tailed field vole Microtus agrestis. Journal of Animal Ecology, 70(4), 633-640. https://doi.org/10.1046/j.1365-2656.2001.00518.x

Kelly, D. (1994). The evolutionary ecology of mast seeding. Trends in Ecology \& Evolution, 9(12), 465-470. https://doi.org/10.1016/01695347(94)90310-7

Kerr, T. D., Boutin, S., LaMontagne, J. M., McAdam, A. G., \& Humphries, M. M. (2007). Persistent maternal effects on juvenile survival in North American red squirrels. Biology Letters, 3(3), 289-291. https:// doi.org/10.1098/rsbl.2006.0615

Kerr, T. D., \& Descamps, S. (2011). Why do North American red squirrel, Tamiasciurus hudsonicus, mothers relocate their young? A predation-based hypothesis. Canadian Field-Naturalist, 122(1), 65-66. https://doi.org/10.22621/cfn.v122i1.546

Krebs, C. J. (2001). General introduction. In C. J. Krebs, S. Boutin, \& R. Boonstra (Eds.), Ecosystem dynamics of the boreal forest: The Kluane project (pp. 3-8). New York, NY: Oxford University Press. https://doi. org/10.1016/S0006-3495(64)86921-6

Krebs, C. J., Boonstra, R., Kenney, A. J., \& Gilbert, B. S. (2018). Hares and small rodent cycles: A 45-year perspective on predator-prey dynamics in the Yukon boreal forest. Australian Zoologist, 39(4), 724-732. https://doi.org/10.7882/AZ.2018.012

Kuznetsova, A., Brockhoff, P. B., \& Christensen, R. H. B. (2017). ImerTest package: Tests in linear mixed effects models. Journal of Statistical Software, 82(13). https://doi.org/10.18637/jss.v082.i13

Lair, H. (1990). The calls of the red squirrel-A contextual analysis of function. Behaviour, 115(3), 254-282. https://doi.org/10.1163/15685 $3990 \times 00608$

LaMontagne, J. M., \& Boutin, S. (2007). Local-scale synchrony and variability in mast seed production patterns of Picea glauca. Journal of Ecology, 95(5), 991-1000. https://doi.org/10.1111/j.1365-2745.2007.01266.x

LaMontagne, J. M., Peters, S., \& Boutin, S. (2005). A visual index for estimating cone production for individual white spruce trees. Canadian Journal of Forest Research, 35(12), 3020-3026. https://doi. org $/ 10.1139 / \times 05-210$

LaMontagne, J. M., Williams, C. T., Donald, J. L., Humphries, M. M., McAdam, A. G., \& Boutin, S. (2013). Linking intraspecific variation in territory size, cone supply, and survival of North American 
red squirrels. Journal of Mammalogy, 94(5), 1048-1058. https://doi. org/10.1644/12-MAMM-A-245.1

Lane, J. E., McAdam, A. G., Charmantier, A., Humphries, M. M., Coltman, D. W., Fletcher, Q., ... Boutin, S. (2015). Post-weaning parental care increases fitness but is not heritable in North American red squirrels. Journal of Evolutionary Biology, 28(6), 1203-1212. https://doi. org/10.1111/jeb.12633

Larivée, M. L., Boutin, S., Speakman, J. R., McAdam, A. G., \& Humphries, M. M. (2010). Associations between over-winter survival and resting metabolic rate in juvenile North American red squirrels. Functional Ecology, 24(3), 597-607. https://doi.org/10.1111/j.1365-2435.2009. 01680.x

Larsen, K. W., \& Boutin, S. (1994). Movements, survival, and settlement of red squirrel (Tamiasciurus hudsonicus) offspring. Ecology, 75(1), 214-223. https://doi.org/10.2307/1939395

McAdam, A. G., \& Boutin, S. (2003). Variation in viability selection among cohorts of juvenile red squirrels (Tamiasciurus hudsonicus). Evolution, 57(7), 1689-1697. https://doi.org/10.1111/j.0014-3820.2003.tb003 74.x

McAdam, A. G., Boutin, S., Sykes, A. K., \& Humphries, M. M. (2007). Life histories of female red squirrels and their contributions to population growth and lifetime fitness. Ecoscience, 14(3), 362. https://doi. org/10.2980/1195-6860(2007)14[362:LHOFRS]2.0.CO;2

Merritt, J. F. (1986). Winter survival adaptations of the short-tailed shrew (Blarina brevicauda) in an Appalachian montane forest. Journal of Mammalogy, 67(3), 450-464. https://doi.org/10.2307/1381276

Metzgar, L. H. (1967). An experimental comparison of screech owl predation on resident and transient white-footed mice (Peromyscus leucopus). Journal of Mammalogy, 48(3), 387-391. https://doi.org/ 10.2307/1377771

Millar, J. S., \& McAdam, A. G. (2001). Life on the edge: The demography of short-season populations of deer mice. Oikos, 93, 69-76. https:// doi.org/10.1034/j.1600-0706.2001.930107.c

Morrison, S. F., \& Hik, D. S. (2007). Demographic analysis of a declining pika Ochotona collaris population: Linking survival to broad-scale climate patterns via spring snowmelt patterns. Journal of Animal Ecology, 76, 899-907. https://doi.org/10.1111/j.1365-2656.2007.01276.x

Morrison, S. F., Pelchat, G., Donahue, A., \& Hik, D. S. (2009). Influence of food hoarding behavior on the over-winter survival of pikas in strongly seasonal environments. Oecologia, 159(1), 107-116. https:// doi.org/10.1007/s00442-008-1197-5

Morrissey, M. B., \& Ruxton, G. D. (2018). Multiple regression is not multiple regressions: The meaning of multiple regression and the non-problem of collinearity. Philosophy, Theory, and Practice in Biology, 10, 003. https://doi.org/10.3998/ptpbio.16039257.0010.003

O'Connor, C. M., Norris, D. R., Crossin, G. T., \& Cooke, S. J. (2014). Biological carryover effects: Linking common concepts and mechanisms in ecology and evolution. Ecosphere, 5(3), 28. https://doi. org/10.1890/ES13-00388.1

O'Donoghue, M. (1994). Early survival of juvenile snowshoe hares. Ecology, 75(6), 1582-1592. https://doi.org/10.2307/1939619

O'Donoghue, M., Boutin, S., Hofer, E. J., \& Boonstra, R. (2001). Other mammalian predators. In C. J. Krebs, S. Boutin, \& R. Boonstra (Eds.), Ecosystem dynamics of the boreal forest: The Kluane project (pp. 325-336). New York, NY: Oxford University Press.

O'Donoghue, M., Boutin, S., Krebs, C. J., Murray, D. L., \& Hofer, E. J. (1998). Behavioural responses of coyotes and lynx to the snowshoe hare cycle. Oikos, 82, 169-183. https://doi.org/10.2307/3546927

O'Donoghue, M., Boutin, S., Krebs, C. J., Zuleta, G., Dennis, L., Donoghue, M. O., ... Hofer, E. J. (1998). Functional responses of coyotes and lynx to the snowshoe hare cycle. Ecology, 79(4), 1193-1208. https://doi. org/10.1890/0012-9658(1998)079[1193:FROCAL]2.0.CO;2

Oli, M. K., \& Dobson, F. S. (2003). The relative importance of life-history variables to population growth rate in mammals: Cole's prediction revisited. The American Naturalist, 161(3), 422-440. https://doi.org/10.1086/367591

Pryde, M. A., O'Donnell, C. F. J., \& Barker, R. J. (2005). Factors influencing survival and long-term population viability of New Zealand longtailed bats (Chalinolobus tuberculatus): Implications for conservation. Biological Conservation, 126(2), 175-185. https://doi.org/10.1016/ J.BIOCON.2005.05.006

R Core Team. (2017). R: A language and environment for statistical computing. Vienna, Austria: R Foundation for Statistical Computing. Retrieved from https://www.R-project.org/

Réale, D., Garant, D., Humphries, M. M., Bergeron, P., Careau, V., \& Montiglio, P.-O. (2010). Personality and the emergence of the paceof-life syndrome concept at the population level. Philosophical Transactions of the Royal Society of London. Series B, Biological Sciences, 365(1560), 4051-4063. https://doi.org/10.1098/rstb.2010.0208

Rödel, H. G., Bora, A., Kaetzke, P., Khaschei, M., Hutzelmeyer, H., \& von Holst, D. (2004). Over-winter survival in subadult European rabbits: Weather effects, density dependence, and the impact of individual characteristics. Oecologia, 140(4), 566-576. https://doi.org/10.1007/ s00442-004-1616-1

Rödel, H. G., Zapka, M., Talke, S., Kornatz, T., Bruchner, B., \& Hedler, C. (2015). Survival costs of fast exploration during juvenile life in a small mammal. Behavioral Ecology and Sociobiology, 69(2), 205-217. https:// doi.org/10.1007/s00265-014-1833-5

Rodríguez, S., van Noordwijk, A. J., Álvarez, E., \& Barba, E. (2016). A recipe for postfledging survival in great tits Parus major: Be large and be early (but not too much). Ecology and Evolution, 6(13), 4458-4467. https://doi.org/10.1002/ece3.2192

Schielzeth, H. (2010). Simple means to improve the interpretability of regression coefficients. Methods in Ecology and Evolution, 1(2), 103-113. https://doi.org/10.1111/j.2041-210X.2010.00012.x

Schorr, R. A., Lukacs, P. M., \& Florant, G. L. (2009). Body mass and winter severity as predictors of overwinter survival in Preble's meadow jumping mouse. Journal of Mammalogy, 90(1), 17-24. https://doi. org/10.1644/07-MAMM-A-392.1

Searcy, S. P., \& Sponaugle, S. (2001). Selective mortality during the larvalJuvenile transition in two coral reef fishes. Ecology, 82(9), 2452-2470. https://doi.org/10.1890/0012-9658(2001)082[2452:SMDTLJ]2. $0 . \mathrm{CO} ; 2$

Silvertown, J. W. (1980). The evolutionary ecology of mast seeding in trees. Biological Journal of the Linnean Society, 14(2), 235-250. https:// doi.org/10.1111/j.1095-8312.1980.tb00107.x

Smith, C. C. (1968). The adaptive nature of social organization in the genus of tree squirrels Tamiasciurus. Ecological Monographs, 38(1), 31-64. https://doi.org/10.2307/1948536

Stamps, J. A. (2007). Growth-mortality tradeoffs and "personality traits" in animals. Ecology Letters, 10(5), 355-363. https://doi. org/10.1111/j.1461-0248.2007.01034.x

Steele, M. A. (1998). Tamiasciurus hudsonicus. Mammalian Species, 586(586), 1-9. https://doi.org/10.1890/0012-9623(2004)85

Stuart-Smith, A. K., \& Boutin, S. (1995). Predation on red squirrels during a snowshoe hare decline. Canadian Journal of Zoology, 73(4), 713-722. https://doi.org/10.1139/z95-083

Studd, E. K., Boutin, S., McAdam, A. G., Krebs, C. J., \& Humphries, M. M. (2015). Predators, energetics and fitness drive neonatal reproductive failure in red squirrels. Journal of Animal Ecology, 84(1), 249-259. https://doi.org/10.1111/1365-2656.12279

van der Jeugd, H., \& Larsson, K. (1998). Pre-breeding survival of barnacle geese Branta leucopsis in relation to fledgling characteristics. Journal of Animal Ecology, 67, 953-966. https://doi.org/10.1046/ j.1365-2656.1998.6760953.x

Whitham, T. G. (1986). Costs and benefits of territoriality: Behavioral and reproductive release by competing aphids. Ecology, 67(1), 139-147. https://doi.org/10.2307/1938512 
Williams, C. T., Gorrell, J. C., Lane, J. E., McAdam, A. G., Humphries, M. M., \& Boutin, S. (2013). Communal nesting in an 'asocial' mammal: Social thermoregulation among spatially dispersed kin. Behavioral Ecology and Sociobiology, 67(5), 757-763. https://doi.org/10.1007/ s00265-013-1499-4

Williams, C. T., Lane, J. E., Humphries, M. M., McAdam, A. G., \& Boutin, S. (2014). Reproductive phenology of a food-hoarding mast-seed consumer: Resource- and density-dependent benefits of early breeding in red squirrels. Oecologia, 174(3), 777-788. https://doi.org/10.1007/ s00442-013-2826-1

Wunder, B. A., Dobkin, D. S., \& Gettinger, R. D. (1977). Shifts of thermogenesis in the prairie vole. Oecologia, 29, 11-26. https://doi. org/10.1007/BF00345359

\section{SUPPORTING INFORMATION}

Additional supporting information may be found online in the Supporting Information section.

How to cite this article: Hendrix JG, Fisher DN, Martinig AR, et al. Territory acquisition mediates the influence of predators and climate on juvenile red squirrel survival.

J Anim Ecol. 2020;89:1408-1418. https://doi.

org/10.1111/1365-2656.13209 